Türkiye Tarımsal Araştırmalar Dergisi
http://dergi.siirt.edu.tr $\begin{aligned} & \text { Turk J Agric Res } \\ & \text { (2015) 2: 15-27 } \\ & \text { TÜTAD } \\ & \text { ISSN: 2148-2306 }\end{aligned}$

\title{
Madendere Havzası Topraklarında Arazi Kullanım/Arazi Örtüsü ile Bazı Erozyon Duyarlılık İndeksleri Arasındaki İlişkinin Belirlenmesi*
}

\author{
Ekrem KANAR, Orhan DENGIZ*** \\ Ondokuz Mayıs Üniversitesi, Ziraat Fakültesi, Toprak Bilimi ve Bitki Besleme Bölümü, Samsun, TÜRKİY
}

\begin{abstract}
Geliş Tarihi/Received: 23.02 .2015
Kabul Tarihi/Accepted: 07.03.2015

** Sorumlu Yazar/Correspondence: o_dengiz@hotmail.com

Özet: Dünyanın birçok bölgesi için, verimli toprak katmanlarını taşıyıp toprak üretkenliğini azaltan, topraktaki organik madde miktarını ve besin maddelerini azaltıp toprağı sığlaştırarak arazi bozulmasına neden olan en önemli olaylardan birisi toprak erozyondur. Bu nedenle erozyon araştırmaları toprakla ilgili yapılan araștırmalar arasında önemli bir yer tutmaktadır. $\mathrm{Bu}$ çalışmanın amacı Madendere Havzası topraklarında arazi kullanım/arazi örtüsü ile bazı erozyon duyarlılık indeksleri arasındaki ilişkinin belirlenmesidir. Havzanın arazi kullanımı ve arazi örtü dağılımı belirlemek için Geoeye-2013 uydu görüntüsü kullanılmıştır. Orman örtüsü havzanın en geniş alanını kaplarken (\% 38.6), toplam alanın \% 3.6 ile yerleşim alanı en az dağılım alanına sahiptir. Havzadan grid yöntemine göre her $200 \mathrm{~m}$ mesafeden ve $0-20 \mathrm{~cm}$ den toprak derinliğindenalınan 71 adet toprak örneklerinde erozyon oranı, dispersiyon oranı, erodobilite, agregat stabilitesi belirlenerek havza topraklarının erozyona hassaslıkları belirlenmiştir. Farklı arazi kullanımı ve arazi örtüsünden alınan toprak örneklerinde yapılan aşınıma duyarlılık analizleri sonuçlarına göre, havza topraklarının erozyona karşı yüksek derecede duyarlı oldukları belirlenmiş ve bu duruma karşı alınması gereken önlemlere yönelik önerilerde bulunulmuştur.
\end{abstract}

Anahtar Kelimeler: Erozyona duyarlılık indeksleri, arazi kullanım/arazi örtüsü, Madendere Havzası

\section{Determination of Relatinship Between Land Use/Land Cover and Some Erodibility Indexes in Madendere Watershed Soils}

\begin{abstract}
In many regions of the world, soil erosion is one of the main land degradation processes that reduce the soil productivity by removing fertile topsoil layers, thus decreasing levels of organic matter and the nutrients. Therefore erosion researches constitute an important part of the research on the soils. The aim of this research is the determination of the relationship between land use/land cover and some erodibility indices in Madendere Watershed soils. Land use and land cover classes were generated from Geoeye-2013 image data classification. Forest is the highest land cover in the study area and has about $38.6 \%$ of the total area, while the lowest land cover is settlement which is about $3.6 \%$. Erosion ratio, dispersion ratio, soil erodibility and aggregate stability were determined for 71 each soil samples collected according to grid method from each $200 \mathrm{~m}$ distance point and $0-20 \mathrm{~cm}$ soil depth in Watershed. According to the results of erodibility analysis for soil samples taken from different land uses and land covers, it was determined that the soils of watershed are high erodible soils. For ${ }^{1}$ that reason, it was given some suggestions to take some mesurments for this watershed.
\end{abstract}

Keywords: Erodibility indexes, land use/land cover, Madendere Watershed

*Bu çalışma Ondokuz Mayıs Üniversitesi Fen Bilimleri Enstitüsü Yüksek Lisans Tez çalışmasından üretilmiştir. 


\section{Giriş}

Toprak, hava ve su gibi yerküreyi saran en önemli doğal kaynaklardan birisidir. Karasal ekosistemde yaşayan mikro-makro ve flora-faunaya ait tüm canlılar, besin ihtiyaçlarını doğrudan veya dolaylı olarak topraktan sağlar ve tüm canlılar toprak içerisinde veya üzerinde yaşamlarını sürdürürler. $\mathrm{Bu}$ nedenle, tüm canlıların yaşam süreçleri toprak varlığıyla paralellik göstermesi ve bu varlığın ekosistem içerisinde korunması ve devamlılığının sağlanması; öncelikle onların karakteristiklerinin belirlenmesi ve bu karakteristiklerine, kapasitelerine ve potansiyellerine yönelik akılc1 yönetim planlarının yapılmasına bağlıdır.

Toprak oluşumunu hılandırmak mümkün olmadığı gibi, toprak varlığını suni olarak da arttırmak mümkün değildir. $\mathrm{Bu}$ nedenle toprak konusunda diğer doğal kaynaklara oranla daha hassas olmak gerekir. İnsan, bitki ve hayvan hayatında önemli bir etkisi olan toprak, ekolojik, biyolojik, ekonomik ve kültürel fonksiyonları ile en önemli doğal kaynaklarımızdan birisidir. Ancak gerekli önlemlerin alınmaması, aşırı ve yanlış kullanım ve doğal etmenlere karşı etkili korunmaması nedeniyle giderek kaybolmaktadır.

Toprak erozyonu konusunda pek çok araștırmalar yapılmıș ve yöntemler geliștirilmiştir. Erozyonun nedenleri bilinmekle beraber nedensel etmenlerin ölçülmesi, etkileme koşulları, etmenler arasındaki etkileşimin sonuca yansıma ağırlığı, derecesi ve sayısal değerini saptamak hayli karmaşıktır. Ayrıca geniş alanlarda toprak erozyon çalışmalarının yürütülmesi, hem zaman alıcı, hem de maliyeti yüksek çalışmalardır. $\mathrm{Bu}$ nedenle araştırmacılar toprakların erozyona karş1 duyarlılıklarının hızlı bir şekilde belirlenmesi amacıyla birçok duyarlılık indeksleri geliştirmişlerdir. Middleton (1930), dispersiyon oranın1, süzülme oranını, erozyon oranını ve agregat stabilitesini; Wallis ve Stewan (1961), agregasyon ve dispersiyon oranını; Bryan (I968), erozyon oranını, yüzey agregasyon oranını, kil oranını ve benzeri indeksleri; Balcı ve Özyuvacı (1974), dispersiyon oranın1; Sönmez (1982), kil oranın1, dispersiyon oranın1, erozyon oranın1, geçirgenlik oranını ve Boekel oranını temel alarak toprakların aşınma eğilimlerini ya da erozyona duyarlılıklarını incelemişlerdir.

Toprağın aşınabilirliği, arazinin özelliklerine ve arazi kullanım durumuna bağlı olarak değiştiği gibi yağışın erosivitesine ve arazi kullanım türüne göre de değişebilir. Nitekim su toplama havzaları; tarım, orman, mera, yerleşim alanı ve sanayi işletmeciliği gibi farklı disiplinlerin yer aldığı arazi birimleridir. Fakat havza içerisinde plansız ve amaç dışı arazi kullanımları özellikle toprakların degradasyonuna neden olmaktadır. Arazi degradasyonunu, Wasson (1987) arazinin insanlar için daha az kullanışlı hale gelmesi; De Kimpe ve Warkentin (1998) ise daha özel olarak ekosistemlerdeki toprağın uygun değer işlevini yerine getirememesi olarak tanımlamıştır.

Toprak kaybinı ve dolayısıyla arazi degradasyonunu tespit ederken manüel metotları kullanarak analizler ve manipülasyonlar yapmak pahalı olup zaman kaybına neden olmakta, pratik olarak mümkün olmamaktadır (Aronoff, 1989). 1970'lerin ortalarından beri arazi kullanımını ve değişimini belirlemede uydu görüntüleri kullanılmaya başlanmıştır (Anderson ve ark., 1976). Son on yıldır ise kaynak yönetiminde Coğrafi Bilgi Sistemi (CBS)'nin önemli bir araç olarak kullanıldığ 1 görülmektedir (Hinton, 1996).

$\mathrm{Bu}$ araştırmanın amacı, Madendere Havzası topraklarında arazi kullanım/arazi örtüsü ile bazı erozyon duyarlılık indeksleri ( $\mathrm{K}$ faktörü, agregat stabilitesi, dispersiyon ve erozyon oranı) arasındaki ilişkilerin belirlenmesidir.

\section{Materyal ve Yöntem}

\subsection{Materyal}

Madendere Havzası Kocaeli ili'ne bağlı Kartepe'nin kuzey-doğusunda ve Kartepe Merkeze $14 \mathrm{~km}$ uzaklıktadır. Havza sınırları içerisinde sadece Avluburun Köyü yer almaktadır. Havzaların büyüklük bakımından sınıflandırması göz önüne alındığı zaman Madendere Havzası yaklaşık 5.5 km² kapladığı alan ile "küçük havza" kategorisine girdiği anlaşılmaktadır. Deniz seviyesinden yaklaşık $415 \mathrm{~m}$ yükseklikte bulunan havza $4515500-4518000 \mathrm{~K}$ ve $262400-264800 \mathrm{D}$ (UTM-m) yer almaktadır (Şekil 1).

Araştırma alanı yıllık ortalama yağış miktarı $730.4 \mathrm{~mm}$, y1llık ortalama sicaklık değeri ise 11.3 ${ }^{\circ} \mathrm{C}$ 'dir (Tablo 1). Toprak Taksonomisi (Anonymous, 1999)'ne göre çalışma alanı alan ustic nem rejimi ve mesic sicaklık rejimine sahiptir.

$\mathrm{Bu}$ çalışmada, araştırma alanına ait G24a3 paftası içerisine giren 1:25.000 ölçekli topoğrafik harita temel altlık kartoğrafik materyal olarak kullanılmış ve sayısallaştırılmıştır (Şekil 2). Ayrıca çalışma alanının arazi kullanım ve arazi örtü dağılımını belirlemek amacıyla 2013 yılına ait $0.5 \times 0.5 \mathrm{~m}$ piksel çözünürlükte Geoeye-2013 uydu görüntüsü kullanılmıştır (Şekil 3). Topoğrafik haritaların sayısallaştırılması, jeoistatistik dağılım haritaların oluşturulmasında ArcGIS $9.3 \mathrm{v}$ coğrafi bilgi sistemi programı kullanılmıştır. 


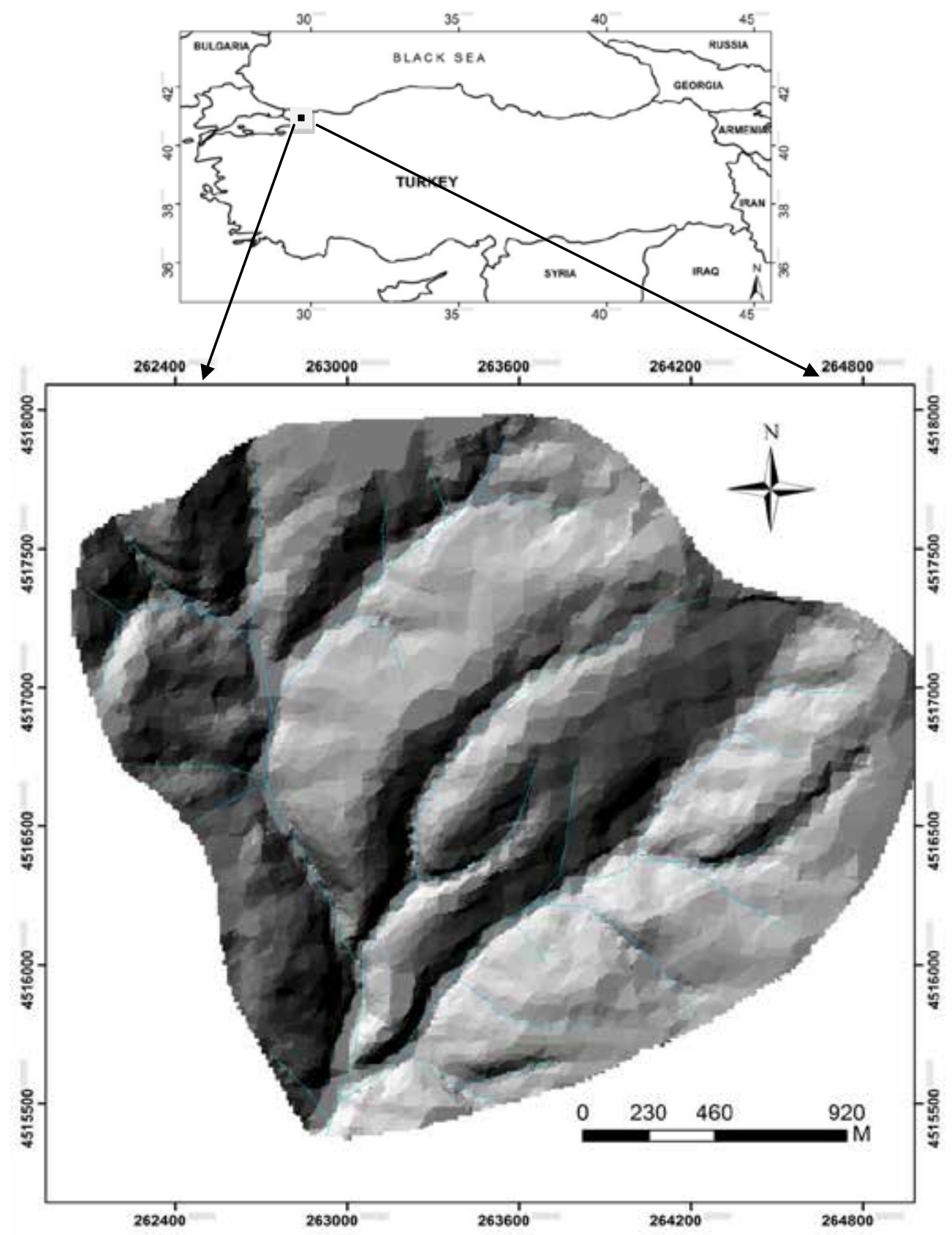

Şekil 1. Çalışma alanı lokasyon haritası

Tablo 1. Çalışma alanı meteorolojik verileri

\begin{tabular}{|c|c|c|c|c|c|c|c|c|c|c|c|c|c|}
\hline & $\begin{array}{l}\text { नैँ } \\
\text { ठै }\end{array}$ & $\begin{array}{l}\overrightarrow{\tilde{E}} \\
\stackrel{\vec{B}}{W}\end{array}$ & $\sum_{\Sigma}^{ \pm}$ & 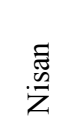 & 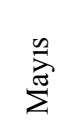 & 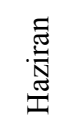 & $\underset{\stackrel{\Xi}{\Xi}}{\stackrel{\Xi}{\Xi}}$ & 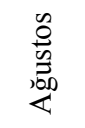 & $\begin{array}{l}\text { 宓 } \\
\text { 至 }\end{array}$ & $\frac{\Xi}{\square}$ & 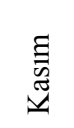 & 並 & Yill1k \\
\hline $\mathrm{T}\left({ }^{\circ} \mathrm{C}\right)$ & 0.0 & 2.0 & 5.8 & 11.0 & 15.5 & 19.5 & 22.0 & 21.5 & 18.0 & 12.2 & 6.5 & 1.9 & 11.3 \\
\hline P mm) & 92.8 & 82 & 78.9 & 76.3 & 57.7 & 40.3 & 14.6 & 15.1 & 26.6 & 54.7 & 85.4 & 106 & 730.4 \\
\hline
\end{tabular}




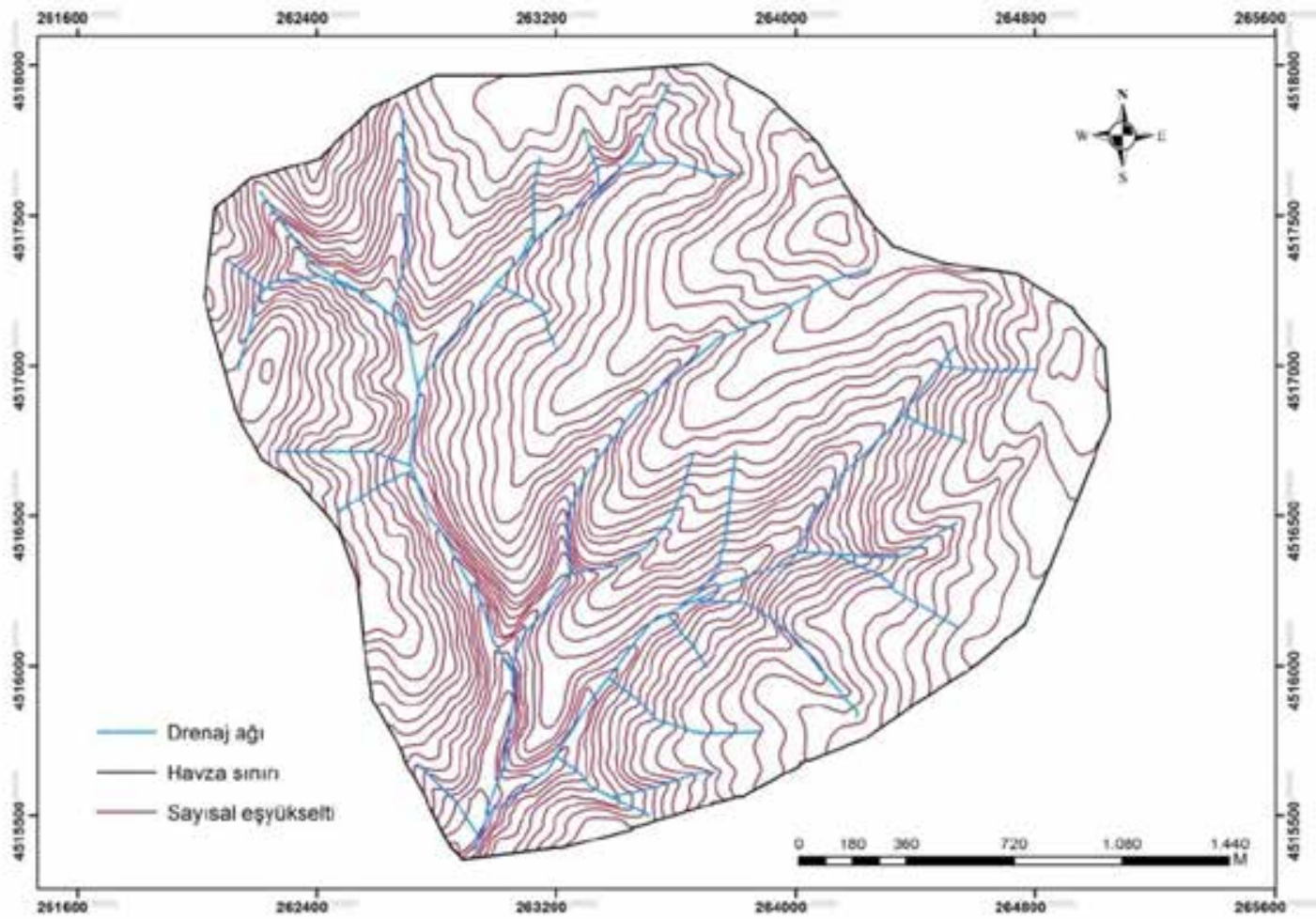

Şekil 2. Çalışma alanına ait sayısal eşyükselti haritası

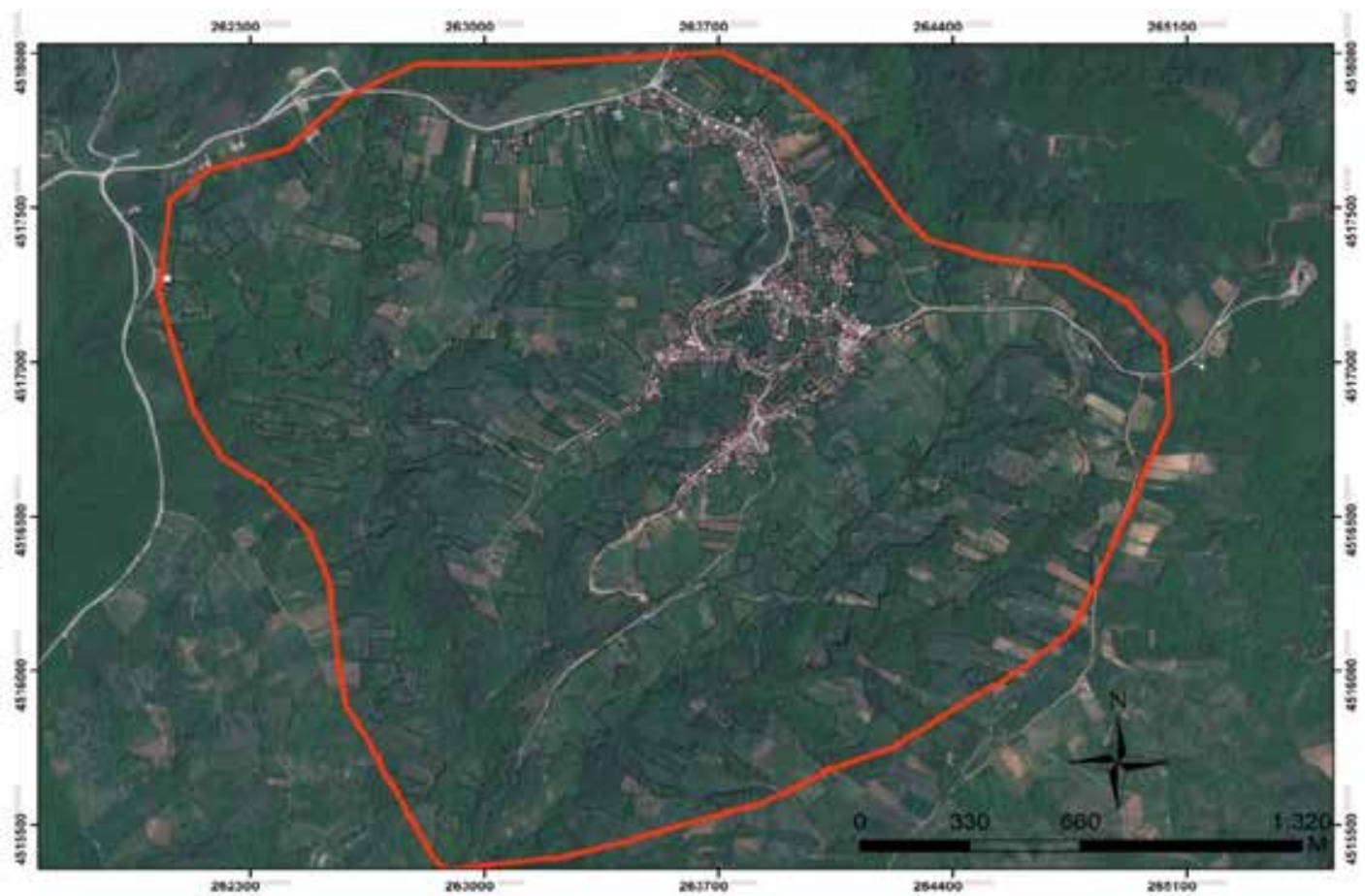

Şekil 3. Çalışma alanı 2013 yılına ait Geoeye uydu görüntüsü 


\subsection{Yöntem}

\subsubsection{Toprakların aşınıma duyarlılıklarda kullanılan bazı erozyon indeksleri}

Agregat stabilitesi (AS): Yoder tipi eleme setinde 1slak eleme yöntemine göre belirlenmiştir (Kemper ve Rosenau, 1986).

Dispersiyon oranı (DO): Süspansiyonda dispers edilmeden ölçülen silt+kil \% değerinin, mekanik analizde ölçülen silt+kil \% değerine oranlanmasıyla hesaplanmıştır (Lal, 1988).

Erozyon oranı (EO): Toprakların nem eşdeğeri değerinin mekanik analizde ölçülen kil değerine oranlanması ve buradan elde edilen sonucun DO ile çarpılması yoluyla hesaplanmıştır (Lal, 1988).

Erodobilite faktörü (USLE-K): K faktörü, her bir noktasal toprak örneği için yapılacak laboratuvar analizine dayalı olarak aşağıdaki ampirik eşitlikten yararlanılarak belirlenir (Wischmeier ve Smith, 1978).

$100 K=\left[2,1 \times 10^{-4} \cdot(M)^{1.14} \cdot(12-a)+3,25(b-2)+2,5 \cdot(c-3)\right] \cdot 1,292$

Bu eşitlikte;

$\mathrm{K}=$ Toprağın erozyona duyarlılı̆ ${ }_{1}$

$\mathrm{M}=$ Tane büyüklüğü dağılımı parametresi

$\mathrm{M}=($ Çok ince kum, $\%+$ silt, \%). (100+kil, \%)

$\mathrm{a}=$ Organik madde içeriği ( $\%)$

$\mathrm{b}=$ Strüktür tipi ve sınıfi kodu

$\mathrm{c}=$ Hidrolik geçirgenlik sınıfı kodu

$1.292=$ Metrik sisteme dönüştürme sabitesi
$\mathrm{Bu}$ eşitlikten çıkan sonuçlara göre belirlenen $\mathrm{K}$ sınıfları; 0.0-0.05 arasındaki değerlerde çok düşük, 0.05-0.1 olanlar düşük, 0.1-0.2 aralığındaki değerlerde orta, 0.2-0.4 arasında yüksek, 0.4-0.6 aralığında çok yüksek olmak üzere beş sınıfta tanımlanmıştır (Tablo 2).

Tablo 2. Toprak erodobilite (K) sınıf ve değerleri

\begin{tabular}{ccl}
\hline Sınıf & Değer & Tanımlama \\
\hline 1 & $0.00-0.05$ & Çok az aşınabilir topraklar \\
2 & $0.05-0.10$ & Az aşınabilir topraklar \\
3 & $0.10-0.20$ & Orta derecede aşınabilir topraklar \\
4 & $0.20-0.40$ & Fazla aşınabilir topraklar \\
5 & $0.40-0.60$ & Çok fazla aşınabilir topraklar \\
\hline
\end{tabular}

\subsubsection{Jeoistatistiksel analiz}

Havza topraklarının erozyona olan duyarlılıklarında kullanılan indekslerin hesaplanması ve alan içerisinde bu indekslerin dağılımlarının belirlenmesi amacıyla jeoistatistiksel metodolojiden yararlanılmıştır. $\mathrm{Bu}$ amaçla alandan grid yöntemine göre her $200 \mathrm{~m}$ aralıklarla toplam 78 yüzey $(0-20 \mathrm{~cm})$ toprak örneği alınmıştır (Şekil 4).

Duyarlılı indekslerine ait haritaların bu şekilde oluşturulmasının nedeni, özellikle farklı arazi kullanımı ve arazi örtüsü altında ve havzalardaki farklı topoğrafyada meydana gelen

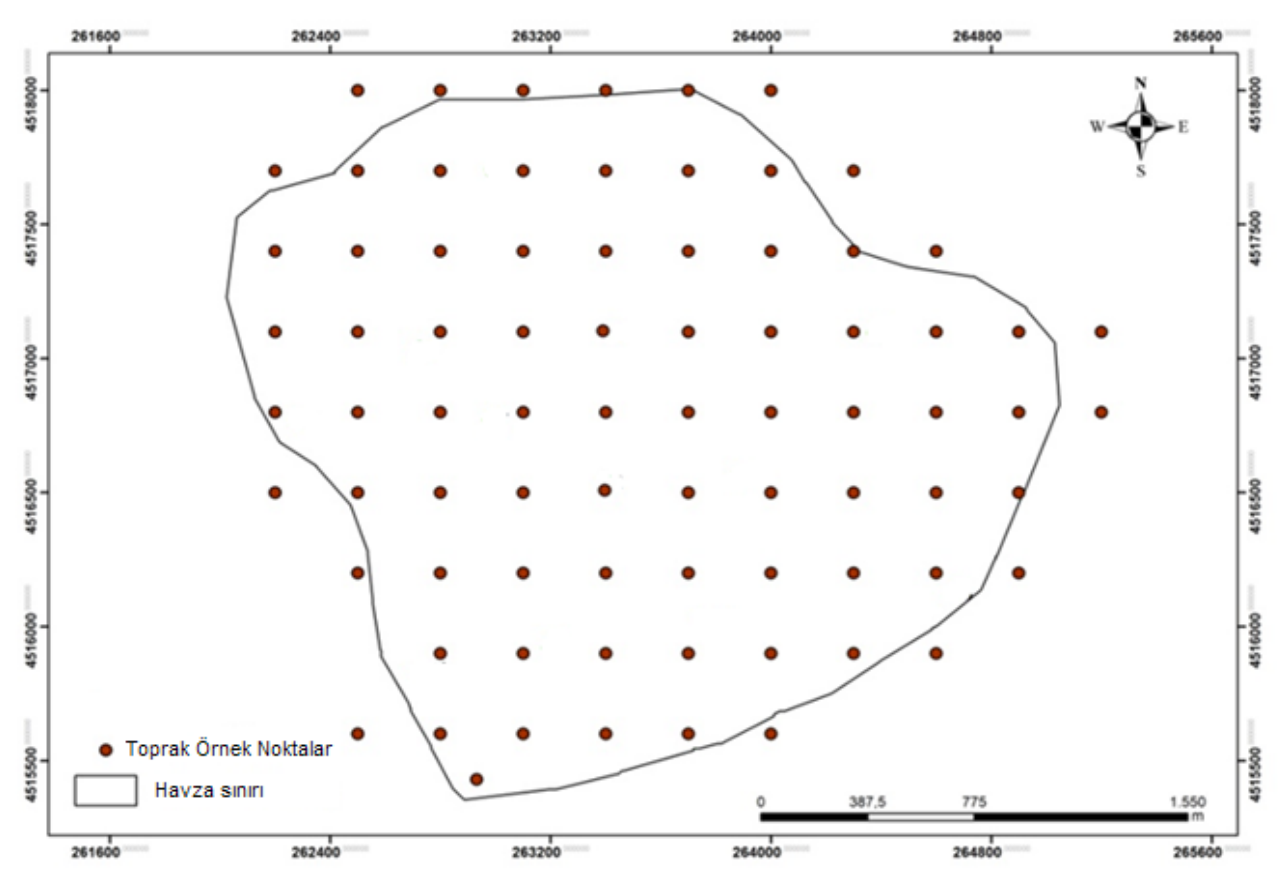

Şekil 4. Çalışma alanında dağılım gösteren yüzey toprak örenekleme deseni 
toprak özellikleri ve kayıplarının kısa mesafelerde değişkenliklerinin yüksek olmasıdır. Bu amaçla, önce toprak özelliklerinin tanımlayıcı istatistikleri hesaplanarak normal dağılıma uygunlukları Kolmogorov-Smirnov testi ile kontrol edilmiştir. Toprak aşınabilirlik özelliklerinin konumsal yapılarının belirlenmesi amacıyla, her bir özellik için aşağıdaki eşitlik kullanılarak deneysel yarıvariogramlar oluşturulmuştur.

$\gamma^{*}(\mathrm{~h})=\frac{1}{2 N(h)} \sum_{i=1}^{N(h)}\left[Z\left(x_{i}\right)-Z\left(x_{i}+h\right)\right]^{2}$

Bu eşitlikte;

h: ayırma uzaklığı (lag)

$\gamma(\mathrm{h})$ : h uzaklığı için semivaryans

$\mathrm{z}\left(\mathrm{x}_{\mathrm{i}}\right)$ : $\mathrm{x}$ noktasında ölçülmüş örnek değeri

$\mathrm{z}\left(\mathrm{x}_{\mathrm{i}}+\mathrm{h}\right): \mathrm{x}+\mathrm{h}$ noktasında ölçülmüş örnek değeri

$\mathrm{N}$ : h ayırma uzaklığ 1 için çiftlerin toplam sayısını tanımlamaktadır.

En uygun deneysel yarıvariogram modeline karar verilirken belirleme katsayısını $\left(\mathrm{R}^{2}\right)$ en yüksek, hata kareler toplamını (HKT) en düşük ve çapraz doğrulama regresyon katsayısını (r) en yüksek tahmin eden model, uygun yarıvariogram modeli olarak kabul edilmiştir. Daha sonra bu modeller kullanılarak toprak özelliklerinin araştırma alanındaki dağılımları blok kriging yöntemi ile belirlenmiştir. Toprak özelliklerinin tanımsal istatistikleri ve normal dağılıma uygunlukları SPSS 17.0 paket programında hesaplanırken, özelliklere ait yarıvariogram modelleri $\mathrm{GS}^{+} 7.0$ paket programında, krigleme haritaları ise ArcMap 9.3 paket programından elde edilmiştir.

\section{Bulgular ve Tartışma}

\subsection{Arazi kullanım ve arazi örtü dağılımı}

Çalışma alanının mevcut arazi kullanımı ve arazi örtü dağılımını belirlemek amacıyla 2013 y1lına ait $0.5 \times 0.5 \mathrm{~m}$ konumsal çözünürlüğe sahip Geoeye uydu görüntüsü kullanılmıştır. Yapılan analiz sonucuna göre başlıca arazi kullanım ve arazi örtü dağılımını; toplam alanın \% 38.6's1 (211.11 ha) ile orman alanları oluştururken, sırasılla meyve bahçeleri ( $\%$ 35.5-192.22 ha), meralık alanlar ( $\%$ 12.8-70.14 ha), işlemeli tarım alanları (\% 9.5, 52.02 ha) ve yerleşim alanları (\% 3.6, 19.74 ha) oluşturmaktadır (Şekil 5).

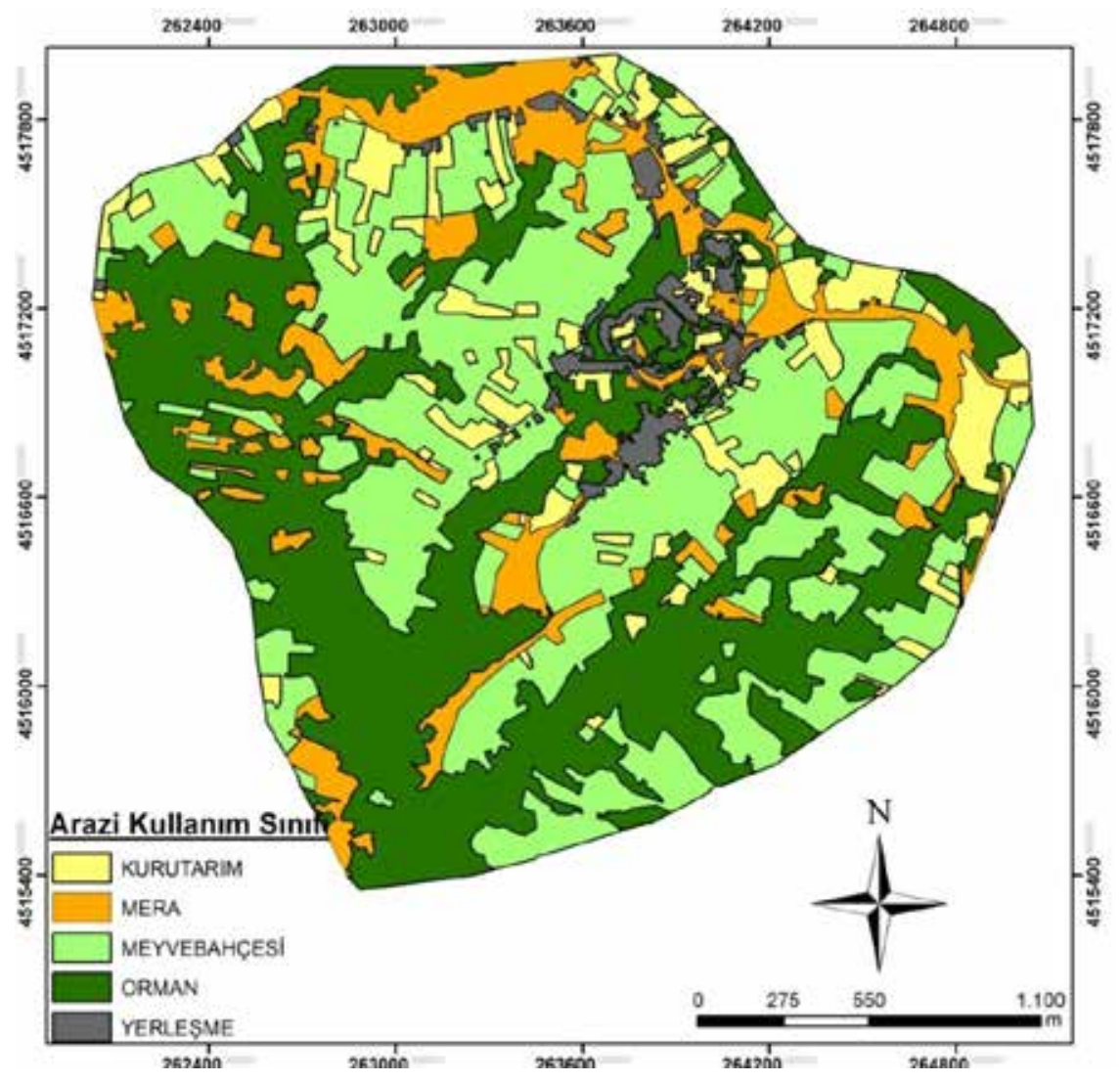

Şekil 5. Çalışma alanına ait arazi kullanımı ve arazi örtü haritası 


\subsection{Havzanın genel topoğrafik özellikleri}

\subsubsection{Eğim}

Çalışma alanı, Mülga Köy Hizmetleri Genel Müdürlüğü'nce yapılan il arazi varlığ1 haritalarında kullanılan standart eğim sınıfları dağılımına yönelik yedi sınıf içerisinde değerlendirildiğinde (Tablo 3 ve Şekil 6); düz ve düze yakın ve hafif eğimli (\% 2-6) araziler toplam alan içerisinde \% 9.41'lik oranı kaplarken, havzanın büyük bir kısmını ise (\% 64.06) çok dik ve çok sarp araziler oluşturmaktadır.

Tablo 3. Çalışma alanı eğim sınıfları dağılımı

\begin{tabular}{llrr}
\hline Eğim Sinıfları & $(\%)$ & \multicolumn{1}{c}{ Alan (ha) } & Oran (\%) \\
\hline $\begin{array}{l}\text { Düz- düze } \\
\text { yakın }\end{array}$ & $(0-2)$ & 407.45 & 7.59 \\
Hafif & $(2-6)$ & 97.46 & 1.82 \\
Orta & $(6-12)$ & 297.95 & 5.55 \\
Dik & $(12-20)$ & 1126.54 & 20.98 \\
Çok dik & $(20-30)$ & 1609.21 & 29.97 \\
Sarp & $(30-45)$ & 1335.90 & 24.88 \\
Çok Sarp & $(45+)$ & 494.50 & 9.21 \\
\hline Toplam & & 5369.00 & 100.0 \\
\hline
\end{tabular}

\subsubsection{Yükseklik ve bakı}

Havzanın yükseklik ve bakı haritaları Şekil 7 ve Şekil 8'de verilmiştir. Havza deniz seviyesinden $130 \mathrm{~m}$ yükseklikte başlayarak 440 m'ye kadar çıkmaktadır. Havzanın genel bakı dağılımı ise çoğunlukla güney, güney batı ve batı yönleri ile kuzey batı yönlerinde dağılım göstermektedir.

\subsection{Toprakların aşınıma duyarlılıklarda kullanılan bazı erozyon indeksleri}

\subsubsection{Erozyon duyarlılık faktörü (USLE-K) oranı}

$\mathrm{K}$ faktörü, birim erozyon indeksi için birim erozyon parselinden elde edilen ortalama toprak kaybı olarak tarif edilmiştir. Rejman ve ark. (1998) toprak erodobilitesindeki değişimleri belirlemek için Güneybatı Polonya'daki lös kuşağında yer alan küçük bir tarım havzasında 3 yıllık tarla denemesi yapmışlardır. Araştırmacılar parsel bazında hesapladıkları $\mathrm{K}$ değerlerinin USLE abağından hesapladıklarına göre 6-10 kez daha küçük olduğunu belirtmişlerdir. Başkan ve Dengiz (2008), Ankara'nın Soğulca Havzası'nda geleneksel ve jeoistatistik yöntemlerle toprağın aşınabilirlik ( $\mathrm{K}$ faktörü) haritasını hazırlamışlardır.

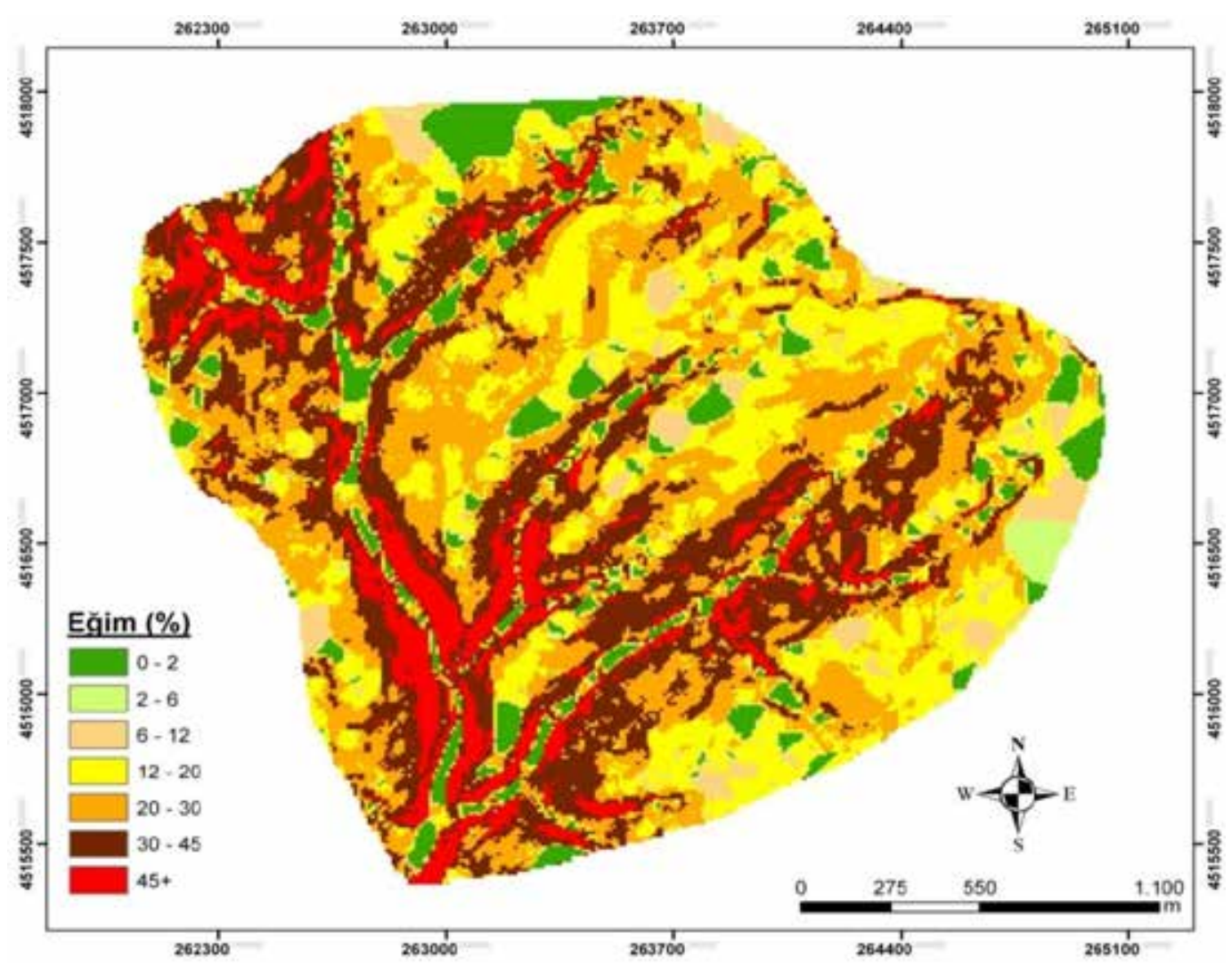

Şekil 6. Çalışma alanı genel eğim dağılım haritası 


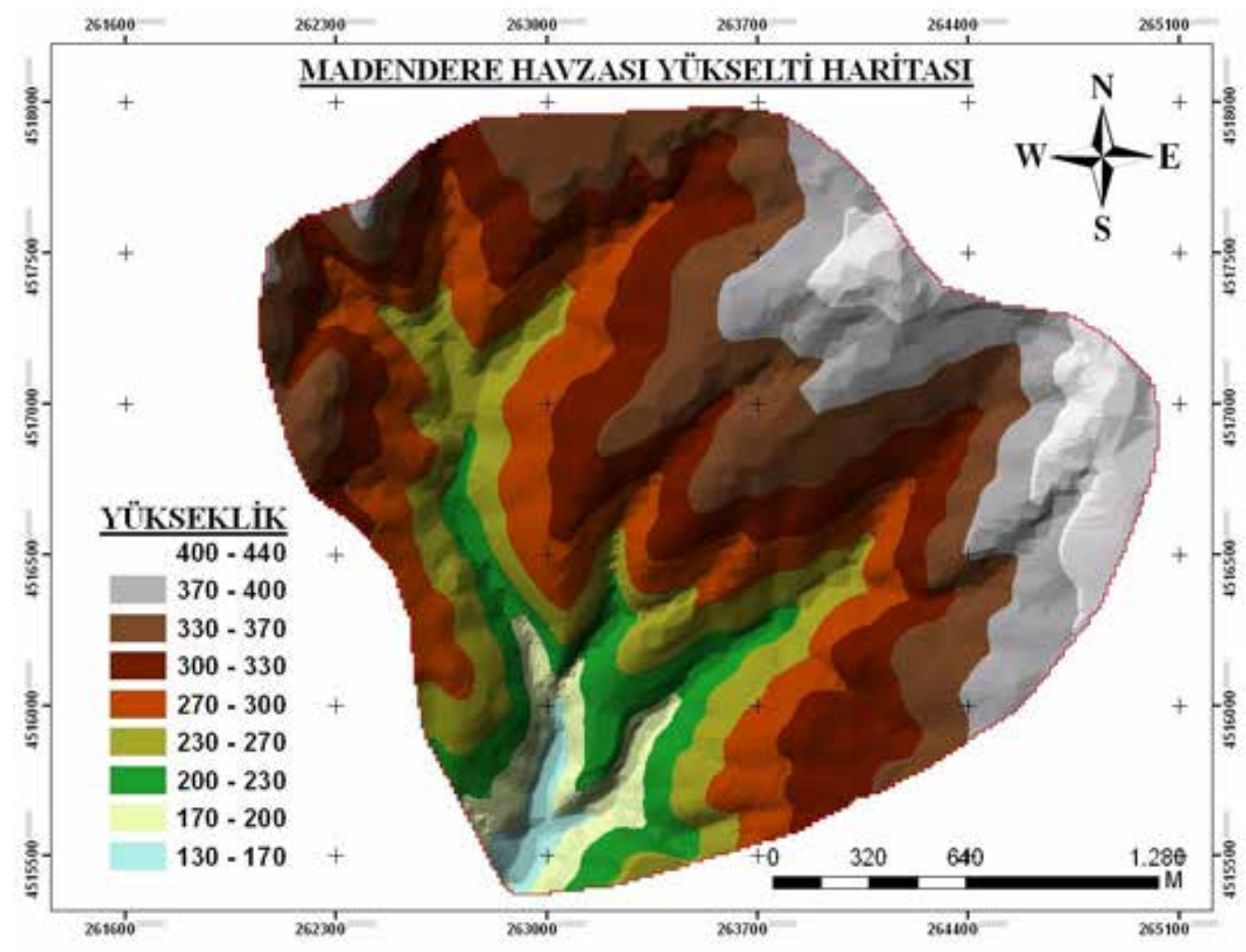

Şekil 7. Havzanın yükseklik haritası

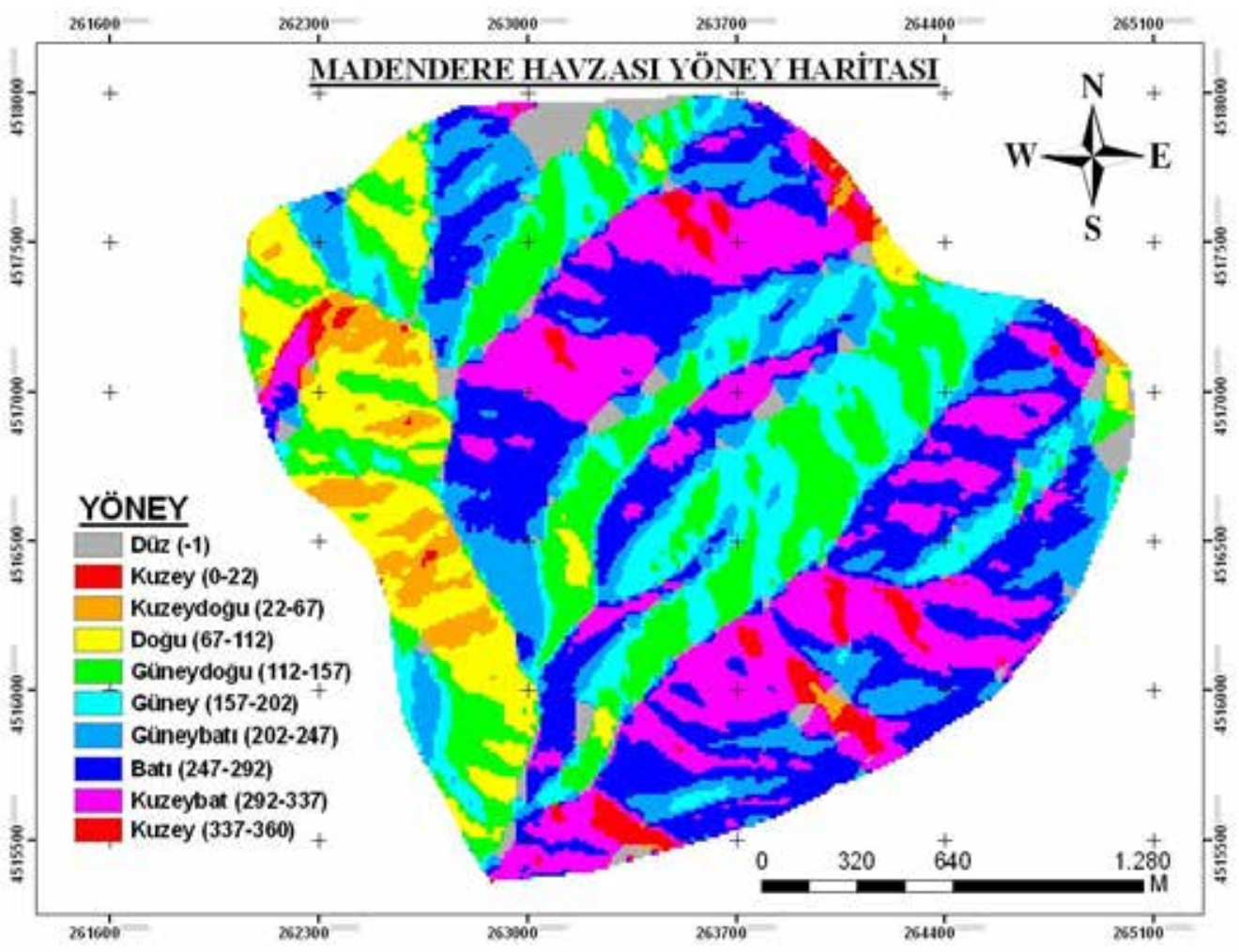

Şekil 8. Havzanın bakı haritası 
Araştırmacılar jeoistatistik yöntemle hazırlanan haritanın daha doğru tahminler verdiğini saptamışlardır.

Havzanın aşınabilirlik (erodobilite) özelliğinin belirlenmesinde çalışma alanından alınan 71 adet yüzey toprağında; toprak bünyesi, toprak geçirgenlik, organik madde, strüktür gibi parametreler kullanılarak Wischmeier ve Smith (1978) tarafindan geliştirilen eşitlik kullanılarak belirlenmiştir. Belirlenen her bir toprak erodobilite değeri (K) jeoistatistik yardımıyla $K$ dağılım haritası oluşturulmuş ve Şekil 9'da verilmiştir. 71 adet toprak örneklerine ait $\mathrm{K}$ değerlerinin temel tanımlayıcı istatistik değerleri Tablo 4'te verilmiştir. Alanın otalama erodobilite değeri 0.19 iken, en düşük ve en yüksek değerler ise 0.01 ve 0.41 arasında değişmektedir. Ayrıca, Şekil 9'da görüldüğü gibi havzanın büyük bir bölümü 0.4-0.5 arası olan çok yüksek derecede erozyona duyarlık sınıfı içerisinde olduğu anlaşılmaktadır. $\mathrm{Bu}$ alanların büyük bir kısmı özellikle kuru tarım alanı

ve meyvecilik alanı olarak kullanılmaktadır. Madendere deresinin geçtiği vadi ve yamaçlar ise çoğunluğu orman örtüsü altında kalmaktadır.

Tablo 4. Çalışma alanı topraklarının erozyon duyarlılık indeksleri olan EF, EO, AS ve DO ait tanımlayıcı istatistikler

\begin{tabular}{lcccc}
\hline $\begin{array}{l}\text { İstatistik } \\
\text { parametreler }\end{array}$ & EF & EO & AS & DO \\
\hline Ortalama & 0.19 & 68.86 & 47.08 & 48.4 \\
Standart sapma & 0.085 & 10.51 & 14.81 & 10.81 \\
Varyans & 0.007 & 110.63 & 219.39 & 116.92 \\
En düşük & 0.01 & 37.1 & 17.45 & 21.31 \\
En yüksek & 0.41 & 86.3 & 73.21 & 67.79 \\
Çarpıklık & 0.16 & -0.88 & -0.14 & -0.35 \\
Basıklık & -0.58 & 0.71 & -1.02 & -0.58 \\
Örnek say1S1 (n) & 71 & 71 & 71 & 71 \\
\hline EF: Erodobilite faktörü (K), EO: Erozyon oranı, AS: Agregat stabilitesi, \\
DO: Dispersiyon oranı
\end{tabular}

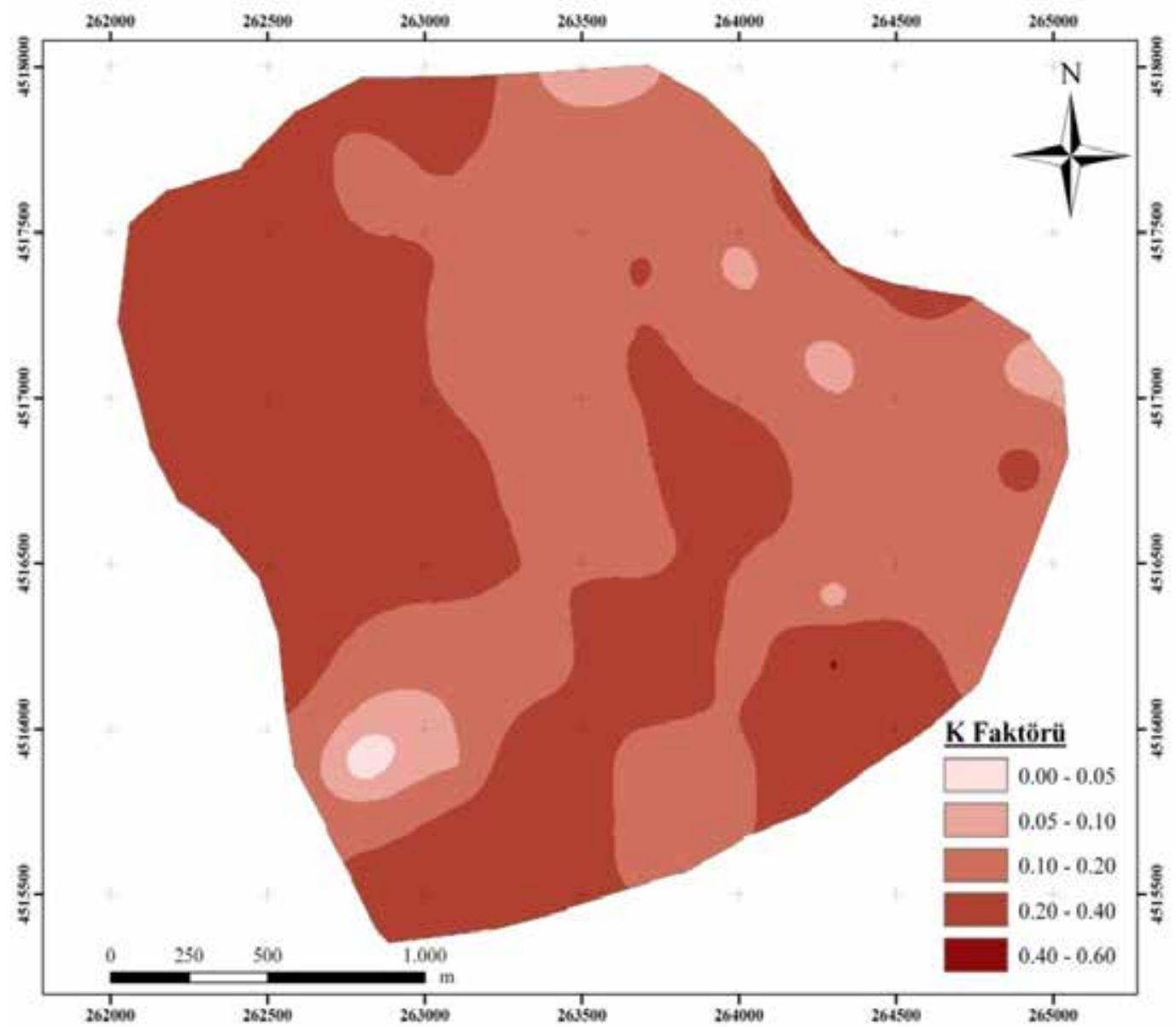

Şekil 9. Havza topraklarının erozyona karşı duyarlılık (erodobilite-K) dağılım haritası 


\subsubsection{Erozyon oranı}

Toprakların erozyona karşı duyarlılıklarını ortaya koymada bir ölçüt olarak kullanılan erozyon oranı için sınır değer “\% 10" olarak kabul edilmiştir. Erozyon oranı \% 10 değerinden büyük olan topraklar erozyona karşı dayanıksız olduğu belirtilmiştir (Bryan, 1968). Bu sınır değer esas alındığında havzanın erozyon oranı değerleri bakımından havzanın tamamı \% 10'un üzerinde olduğu için toprakların erozyona karş1 dayanıklılığı oldukça zayıf olarak belirlenmiştir. Havza topraklarına ait erozyon oranı değerleri bakıldığında \% 37.1 ile \% 86.3 aralığında olduğu ve örneklerin ortalama değeri ise \% 68.86 olarak belirlenmiştir (Tablo 4). Buna karşılık risklilik sınıfı içerisinde özellikle havzanın kuzey kesimlerinde yer alan yüksek arazili üzerindeki tepe üstü düzlükler ile bu kısımların güney bakılarında eğimin artmaya başladığı yamaç arazilerde daha yüksek olduğu belirlenmiştir (Şekil $10)$.

Benzer bir çalışmada Erol ve ark. (2009), Isparta Darıderesi Havzası'nda yapmış oldukları çalışmada orman, tarım ve mera topraklarında sırasılla \% 63.33, 83.45 ve 138.48 sonuçlarını elde etmişlerdir. Bununla birlikte, mera topraklarında tarım ve orman topraklarına oranla daha yüksek bulunduğundan erozyona karşı daha dayanıksız olduğunu belirtmişlerdir.

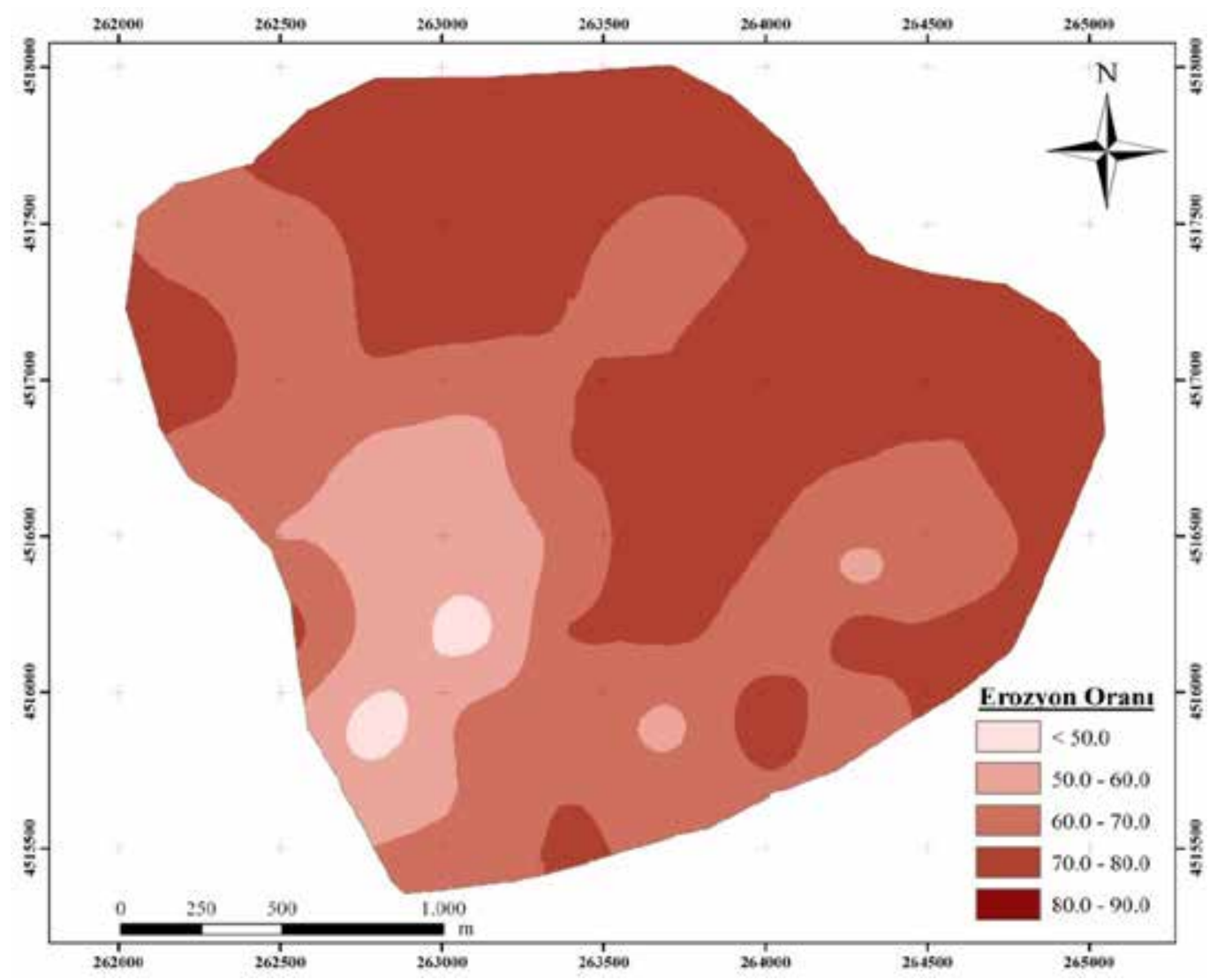

Şekil 10. Havzanın erozyon oranı dağılım haritası

\subsubsection{Agregat stabilitesi}

Toprağın erozyona duyarlılığı esas olarak agregatın strüktürel özellikleri tarafından kontrol edilir (Legout ve ark., 2005). Toprağın erozyona duyarlılığını tahmin etmek için agregat stabilitesinin kullanılması çeşitli araştırmacılarca önerilmiştir (Miller ve Baharrudin, 1987; Bajracharya ve ark., 1992; Barthes ve Roose, 2002; Le Bissonnais ve ark., 2007). Hem makro hem de mikro düzeydeki toprak agregasyonu A.B.D.'deki bazı topraklarda erozyona duyarlılığı tahmin etmek için kullanılmıştır (Wischmeier ve Mannering, 1969). Lehrsch ve Jolley (1992) agregat stabilitesinin mevsimlere göre değişimini incelemişlerdir. Araştırmacılar A.B.D'nin güneyindekilere göre kuzeyindeki toprakların agregat stabilitelerinin daha fazla mevsimsel olarak değiştiğini belirtmişlerdir. 
Çalışma alanının toprak örneklerine ait agregat stabilitesi değerleri Tablo 4'te verilmiştir. Bu değerlere bakıldığında havza topraklarının agregat stabilitesi \% 17.45 ile \% 73.21 arasında değerler almaktadır. Havzadan alınan toprak örneklerinin agregat stabilitesi değerlerinin ortalamasına baktığımızda ise \% 47.08 gibi bir değer karşımıza çıkmaktadır. Havzanın agregat stabilitesi dağılım haritası ise Şekil 11'de verilmiștir. Şekil 11'de de görüldüğü gibi havza topraklarının çok küçük bir bölümünün agregat stabilitesi değerleri \% 20.0'den düşüktür. Havza topraklarının büyük bir çoğunluğu ise \% 50.0'^n üzerinde agregat stabilitesi değerine sahiptir. Yüksek değerler daha çok havzanın orta ve kuzey kesimlerinde dağılım gösterirken, stabilitenin çok düşük olduğu alanlar ise güney ve güney batı kesimlerinde daha fazla dağılım göstermekte ve alanların büyük bir çoğunluğu orman örtüsü altında yer almaktadır.

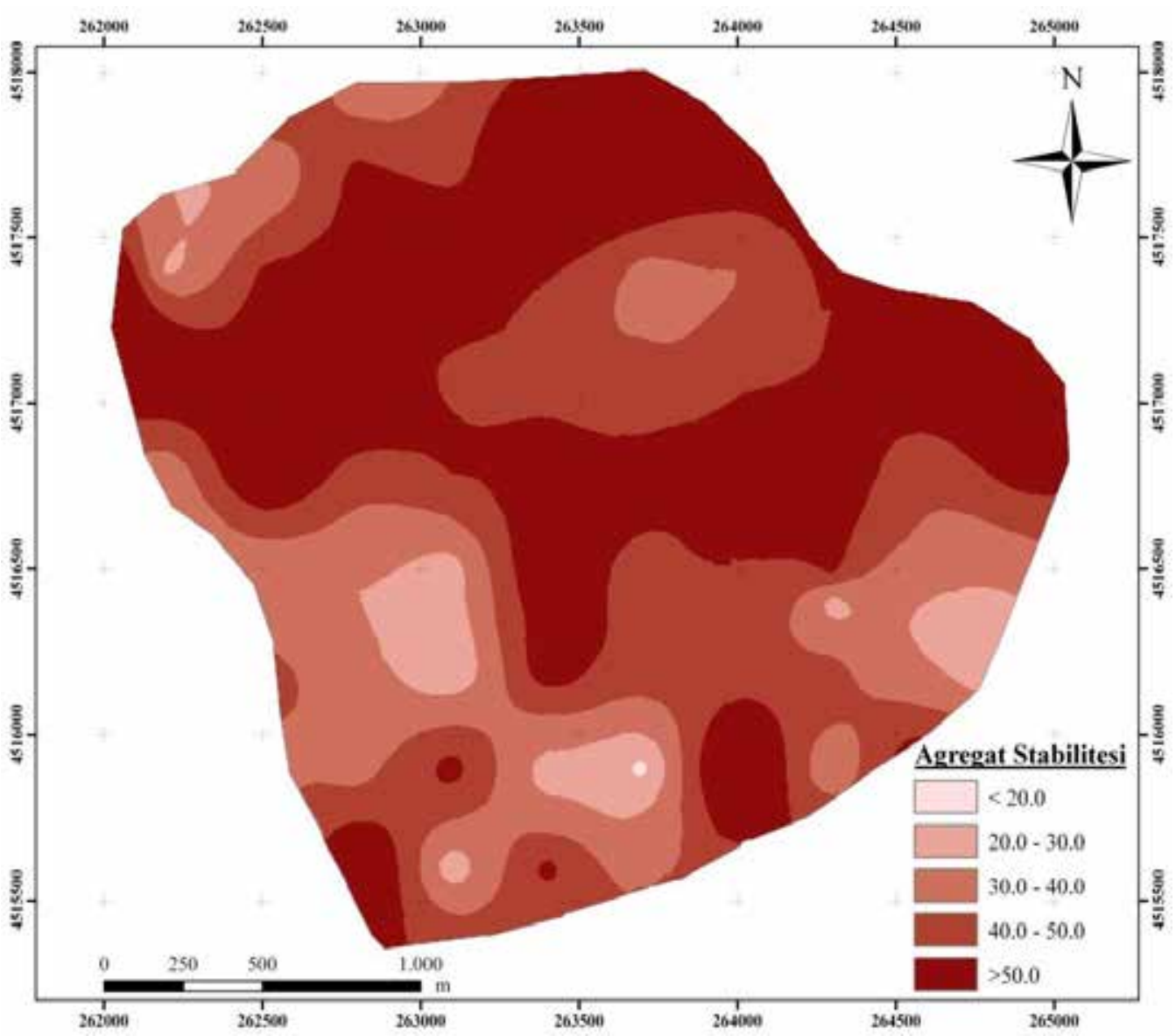

Şekil 11. Havzanın agregat stabilitesi dağılım haritası

\subsubsection{Dispersiyon oranı}

$\mathrm{Bu}$ indeks topraktaki doğal agregatların su ile temas ettiğinde çözülme (dispersleşme) derecesini gösteren bir göstergedir. Eğer topraktaki en küçük boyuta sahip agregatlar dahi suya dayanıklı ise, toprak erozyona dirençli olmaktadır. Bu sebeple toprağın erozyona eğilimini belirlemek amacı ile toprağın dispersiyon analizi yapılmıştır. Çalışma alanına ait toprakların dispersiyon oranı değerleri Tablo 4'te verilmiştir. Havzadan alınan örneklerde yapılan analizler sonucu bulunan dispersiyon oranı değerleri \% 21.31 ile \% 67.79 arasında olduğu belirlenmiştir (Tablo 4). Havzanın ortalama olarak dispersiyon oranı değeri ise \% 48.4 olarak bulunmuştur. Dispersiyon oranı \% 15 'ten küçük olan topraklar erozyona karşı dayanıklıdırlar. Dispersiyon oranı \% 15 'ten büyük olan topraklar ise erozyona karşı dayanıksız oldukları belirtilmektedir (Bryan, 1968).

Havzanın dispersiyon oranı dağılım haritası Şekil 12'de verilmiştir. Haritadan görüleceği gibi havza topraklarının tamamı erozyona karşı 
dayanıksız olduğu anlaşılmaktadır. Fakat bu durumun risklilik özelliğini ortaya koyabilmek amacıyla \% 35 'ten küçük ve \% 65 'ten büyük olmak üzere beş sınıf içerisinde değerlendirilerek, havzanın kuzey ve yüksek kesimlerinde bu parametreye göre topraklar daha fazla risklilik altında yer alırken, güney kesimlerinde azalmaktadır.

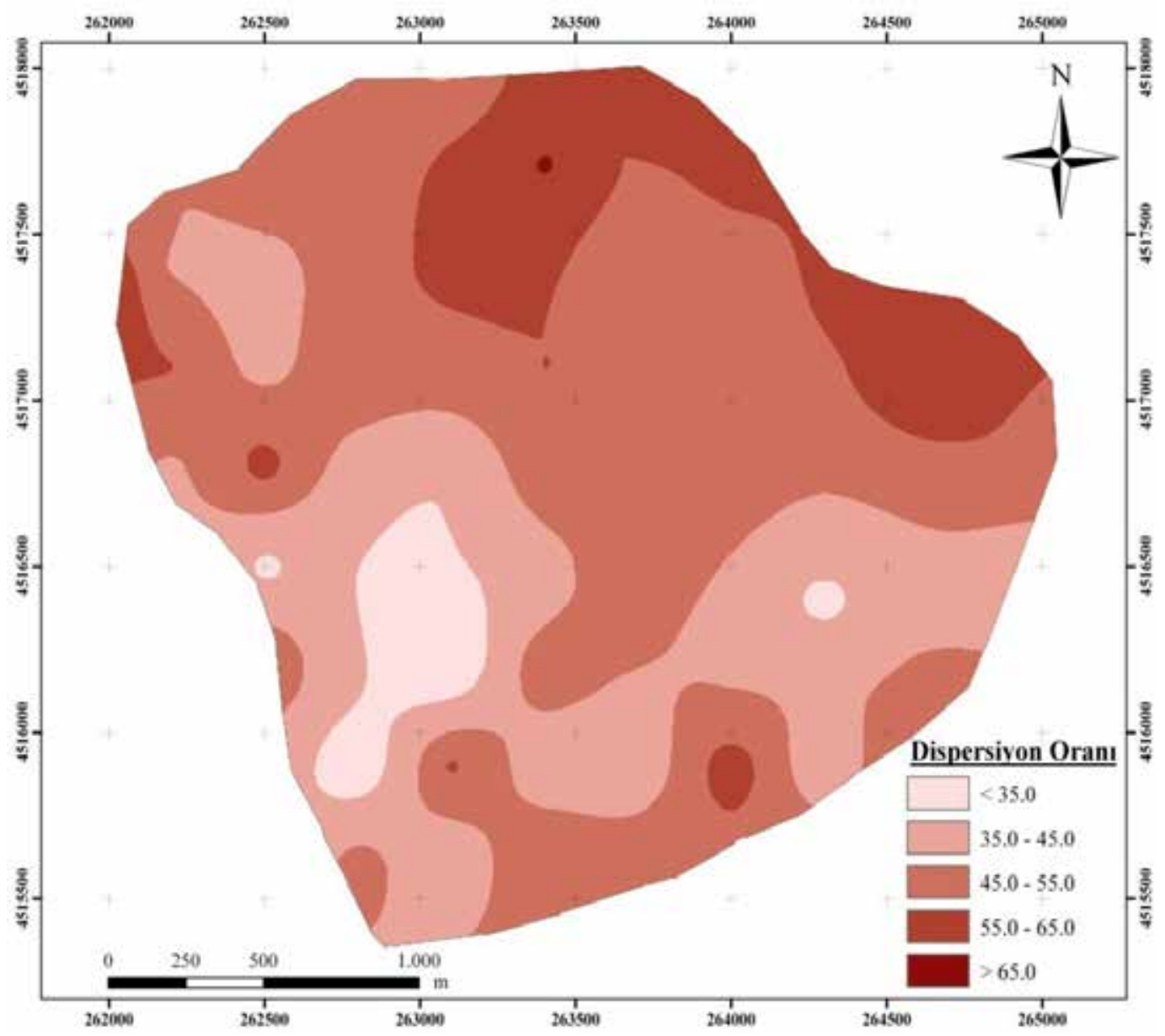

Şekil 12. Havzanın dispersiyon oranı dağılım haritası

\section{Sonuçlar}

Havzadan grid yöntemine göre her $200 \mathrm{~m}$ mesafeden alınan 71 adet toprak örneklerinde ayrica erozyon oranı, dispersiyon oranı, erodobilite, agregat stabilitesi belirlenerek havza topraklarının erozyona hassaslıkları belirlenmiştir. Tüm duyarlılık sınıflarından da görülmektedir ki havza toprakları erozyona karșı büyük duyarlılıkları vardır. Bu durum özellikle eğimi yüksek olan, sığ toprakların yer aldığı alanlar ile tarım yapılan alanlarda daha da fazla duyarlı olduğu belirlenmiştir. Ayrıca orman örtüsünce kaplı vadi ve yamaç alanların yoğun olarak yer aldığı havzanın güney kesimleri bu hali ile korunmalıdır. $\mathrm{Bu}$ alanlardan orman örtüsünün tahrip veya yok edilmesi bu alanlarda yer alan toprakların hızlı bir şekilde taşınmasına neden olacaktır.

Çalışma alanında toprakların erozyon duyarlılıklarını azaltmak, agregat stabilitesi değerini yükseltmek ve $\mathrm{K}$ faktörü değerini düşürmek için toprak koruma yöntemi olarak bitkisel yöntemlere ağırlık verilmelidir. Meyve bahçelerinde örtü bitkisi yetiştirilmeli, bitki ekim nöbeti uygulanmalı, toprağa organik madde ilave edilmelidir. Olanaklar ölçüsünde toprağı çabuk örten ve uzun süre toprak üzerinde kalan bitki türleri seçilmelidir. 


\section{Kaynaklar}

Anderson, J.R., Hardy, E.E., Roach, J.T., Witmer, R.E., 1976. A Land Use and Land Cover Classification System for Use with Remote Sensor Data. U.S. Geological Survey Professional Paper 964, Washington, DC.

Anonymous, 1999. Soil Taxonomy. A Basic of Soil Classification for Making and Interpreting Soil Survey. U.S.D.A Handbook No: 436, Washington D.C.

Aronoff, S., 1989. Geographic Information Systems: A Management Perspective. WLD Publications, Ottawa.

Bajracharya, R.M., Elliot, W.J., Lal, R., 1992. Interrill erodibility of some Ohio soils based on field rainfall simulation. Soil Science Society of America Journal, 56: 267-272.

Balcı, N., Özyuvac1, N., 1974. Türkiye'nin iki farklı bölgesinde yer alan topraklarda erozyon eğiliminin ana materyal, bak1,arazi kullanma şekli ve örnekleme derinliğine bağlı olarak değișimi. İstanbul Üniversitesi Orman Fakültesi Dergisi, Seri A, (2): 79-107.

Barthes, B., Roose, E., 2002. Aggregate stability as an indicator of soil susceptibility to runoff and erosion; validation at several levels. Catena, 47: 133-149.

Başkan, O., Dengiz, O., 2008. Comparision of traditional and geostatistical methods to estimate soil erodibility factor. Arid Land Research and Management, 22: 29-45.

Bryan, R.B., 1968. The development, use and efficiency of indices of soij erodibility. Geoderma, 2: 2-25.

De Kimpe, C.R., Warkentin, B.P., 1998. Soil function and the future of natural resources. Advanges in GeoEcology, 31: 3-10.

Erol, A., Babalık, A.A., Sönmez, K., Serin, N., 2009. Isparta-Darıderesi Havzası topraklarında erozyona duyarlılığın arazi kullanım şekillerine bağlı değişimi. Süleyman Demirel Üniversitesi Orman Fakültesi Dergisi, Seri A, 2: 21-36.

Hinton, J.C., 1996. GIS and remote sensing integration for environmental applications. International Journal of Geographical Information Systems, 10: 877-890.

Kemper, W.D., Rosenau, R.C., 1986. Aggregate stability and size distribution. Editor: Klute, A., Methods of Soil Analysis, Part I-Physical and Mineralocigal
Methods, 2nd ed., SSSA Book Series No: 5, SSA and ASA, Madison, Wisconsin, pp. 425-442.

Lal, R., 1988. Soil erosion research methods. Soil and Water Conservation Society, USA.

Le Bissonnais, Y., Bruand, A., Jamagne, M., 2007. Laboratory experimental study of soil crusting: Relations between aggregate breakdown mechanisms and crust structure. Catena, 16: $377-$ 392.

Legout, C., Leguedois, S., Le Bissonnais, Y., 2005. Aggregate breakdown dynamics under rainfall compared with aggregate stability measurements. European Journal of Soil Science, 56: 225-237.

Lehrsch, G.A., Jolley, P.M., 1992. Temporal changes in wet aggregate stability. Transactions of the ASAE, 35: 493-498.

Middleton, H.E., 1930. Properties of soils which influence erosion. USDA Technical Bulletin 178: 116.

Miller, W.P., Baharrudin, M.K., 1987. Interrill erodibility of highly weathered soils. Communication in Soil Science and Plant Analysis, 18: 933-945.

Rejman, J., Turski, R., Paluszek, J., 1998. Spatial and temporal variations in erodibility of loess soil. Soil and Tillage Research, 46: 61-68.

Sönmez, K., 1982. Van yöresi topraklarında fosforik asit triple süperfosfat ve ahır gübresinin agregasyon agregat stabilitesi ve kırılma değeri üzerine etkileri. Profesörlük takdim tezi (Basılmamış), Atatürk Üniversitesi Ziraat Fakültesi, Erzurum.

Wallis, J.R., Stewan, L., 1961. Erodibility of some california Midlands soils related to their cations exchange capacity. J. Geop. Res., 66: 1225-1230.

Wasson, R., 1987. Detection and measurement of land degradation processes. In Chisholm A, Dumsday R (eds), Land Degradation: Problems and Policies, Cambridge University Press, Melbourne, pp. 49-69.

Wischmeier, W.H., Mannering, J.V., 1969. Relations of soil properties to its erodibility. Soil Science Society of America Proceedings, 33: 131-137.

Wischmeier, W.H., Smith, D.D., 1978. Predicting rainfall erosion losses: A guide to conservation planning. Agricultural Handbook No: 537. United States Department of Agricultural Science and Education Administration, Agricultural Research, Washington, DC. 